\title{
A VECTOR CARRYING THE GFP GENE (Green fluorescent protein) AS A YEAST MARKER FOR FERMENTATION PROCESSES
}

\author{
Luiz Humberto Gomes ${ }^{1 *}$; Keila Maria Roncato Duarte1,2; Felipe Gabriel Andrino ${ }^{1,2}$; Ana Maria \\ Brancalion Giacomelli ${ }^{1}$; Flavio Cesar Almeida Tavares ${ }^{1}$ \\ ${ }^{1}$ Depto. de Genética - USP/ESALQ, C.P. 83 - CEP: 13418-900 - Piracicaba, SP. \\ ${ }^{2}$ Bolsista FAPESP. \\ ${ }^{*}$ Corresponding author <luhgomes@carpa.ciagri.usp.br>
}

\begin{abstract}
Contaminant yeasts spoil pure culture fermentations and cause great losses in quality and product yields. They can be detected by a variety of methods although none being so efficient for early detection of contaminant yeast cells that appear at low frequency. Pure cultures bearing genetic markers can ease the direct identification of cells and colonies among contaminants. Fast and easy detection are desired and morphological markers would even help the direct visualization of marked pure cultures among contaminants. The GFP gene for green fluorescent protein of Aquorea victoria, proved to be a very efficient marker to visualize transformed cells in mixed populations and tissues. To test this marker in the study of contaminated yeast fermentations, the GFP gene was used to construct a vector under the control of the ADH2 promoter (pYGFP3). Since $A D H 2$ is repressed by glucose the expression of the protein would not interfere in the course of fermentation. The transformed yeasts with the vector pYGFP3 showed high stability and high bioluminescence to permit identification of marked cells among a mixed population of cells. The vector opens the possibility to conduct further studies aiming to develop an efficient method for early detection of spoilage yeasts in industrial fermentative processes.
\end{abstract}

Key words: Saccharomyces cerevisiae, GFP (green fluorescent protein), fermentative processes

\section{UM VETOR COM O GENE DA GFP (Green fluorescent protein) PARA A MARCAÇÃO DE LEVEDURAS EM PROCESSOS FERMENTATIVOS}

\begin{abstract}
RESUMO: Leveduras contaminantes podem causar grandes perdas em processos fermentativos quando infectam culturas puras e degradam a qualidade do produto final. Estas leveduras podem ser detectadas por diversos métodos mas nenhum deles oferece resultados com a exatidão e precisão necessárias, quando os contaminantes estão em baixa freqüência. Culturas puras contendo um gene marcador podem ser utilizadas para a direta identificação de células e colônias contaminantes. Detecção rápida e fácil é desejada e marcadores morfológicos podem auxiliar na visualização da cultura marcada. O gene da GFP (green fluorescent protein) extraído da Aequorea victoria mostrou-se eficiente para marcação de células, oferecendo ainda uma fácil visualização das populações e tecidos marcados. Para testar este marcador no estudo de leveduras contaminantes, o gene GFP foi usado para construir um vetor, sob o controle do promotor de ADH2, que é reprimido por glicose, não interferindo assim em nenhuma etapa do processo. A inserção do vetor com a GFP (pYGFP3) em leveduras foi um sucesso, demonstrando alta estabilidade e oferecendo com certeza, um novo método com alta eficiência para o controle de contaminantes em processos fermentativos além de servir como marcador destinado a proteção industrial do material genético.

Palavras-chave: Saccharomyces cerevisiae, GFP (green fluorescent protein), processos fermentativos
\end{abstract}

\section{INTRODUCTION}

The identification of a yeast can be performed by a variety of methods such as serology (Tsuchiya et al., 1965), magnetic ressonance of yeast cell wall (Gorin \& Spencer, 1970), coenzyme Q system (Yamada et al., 1976), amount of nitrogen bases (Kurtzman \& Phaff, 1987), bioluminescence (Miller \& Galston, 1989), trehalose content (Gutierrez, 1990), fat acids properties (Bendová et al., 1991), proton movements and sugar transport (Kilian et al., 1991), inhibitory effect of different compounds (Simpson et al., 1992), differential media, SDS-PAGE, CHEF and RAPD (Tavares et al., 1992 and Gomes, 1995). Each method presents advantages and is suitable for very special research purposes. Some of them have been adapted to study mixed populations of cells and applied in the fermentation industry in order to characterize the occurrence of contaminant yeasts among pure culture cells which spoil the process and bring losses in quality and yield.

The early detection of contaminant yeasts could help to avoid future problems and speed up control measures although with limited range. The ideal situation is to assure the purity of the start culture which can be done by sterilization procedures or the use of selective physical or chemical inhibitors of contaminant yeast growth. The first alternative is too costly for large scale processes and the second require resistant industrial strains which are not usually available. However, Tavares (1995) reported a S. cerevisiae industrial hybrid of good yield and resistant to nystatin, a fungal antibiotic that can be used in the amount of $5 \mathrm{mg} \mathrm{L}^{-1}$ to eliminate contaminant yeasts of the fermentation process. 
The inspection of fermentations for the presence of contaminant yeasts could be improved if morphological marker genes could be introduced in industrial yeasts preserving their technological properties. For this purpose the gene GFP of Aquorea victoria that expresses the Green Fluorescent Protein could help to identify other cells among the population of a marked pure culture. The gene has been found in bacteria (Chalfie et al., 1994), yeast (Kahana et al., 1995), plants (Casper \& Holt (1996); Epel et al., 1996), Drosophila spp. (Wang \& Hazelrigg, 1994) and zebrafish (Amsterdam et al., 1996).

The bioluminescence of GFP helped Cormack et al. (1997) to measure the infection speed in murine kidneys by Candida albicans through optimization of expression of GFP in yeast obtaining the GFP3 gene. This gene was inserted into a plasmid under the control of $\mathrm{ADH} 1$ promoter to transform Candida albicans. The application in industry was tried by Knight et al. (1999) using the GFP gene as a marker in baker yeast to monitor for genotoxic compounds. In the present paper the construction of a yeast vector carrying the GFP gene was done in order to study the expression of the bioluminescence aiming the future development of a simple process for monitoring of spoilage yeast in fermentation processes.

\section{MATERIAL AND METHODS}

Transformation experiments used the strains of Echerichia coli (DH5 $\alpha \mathrm{F}$ '), S. cerevisiae HD 93.15D (MAT a, his 3, leu2, trp1, ura3), S. cerevisiae X2904-3C (MATa, met1, trp1, ura3) and the vectors Bluescript-SKm (Stratagene), pYADE4 (Brunelli \& Pall, 1993) and pYEGFP3 (Cormack et al., 1997).

E.coli $\mathrm{DH} 5 \alpha \mathrm{F}$ ' strain was grown in LB medium (yeast extract $0,5 \%$, tryptone $1 \% \mathrm{NaCl} 1 \%$ and for solid medium, $2 \%$ of agar was added) with ampicillin $50 \mathrm{mg} \mathrm{L}^{-1}$, at $37^{\circ} \mathrm{C}$ under constant $150 \mathrm{rpm}$ agitation. The growth was monitored by measures at $600 \mathrm{~nm}$ in a Beckman spectrophotometer DU640 until reaching $0.5 \mathrm{O}$. D. then the cells were centrifuged at $3000 \mathrm{Xg}$ for 5 minutes. Plasmids were isolated using the Concert High Purity Plasmid Miniprep System (GIBCO-BRL- 11449-014). The restriction enzyme cuttings were done according to product recommendations (GIBCO-BRL). Fragments were isolated using the GFX Gel Band Purification Kit (AmershamPharmacia Biotech - 27-9602-01). Fragments and cloning vectors were bound with T4 DNA ligase (GIBCO-BRL).

$E$. coli cells were prepared for transformation according to the protocols described in Mandel \& Higa (1970), with a modification of the incubation time in the $\mathrm{CaCl}_{2}$, to 2 hours, increasing the number of competent cells in $50 \%$. The transformed bacterial cells were selected in LB medium with ampicillin and X-Gal, according to Miller (1972).

The yeast transformed cells, obtained according to Dohmen et al. (1991) were selected in a minimum medium for Saccharomyces cerevisiae (YNB without aminoacids $0,67 \%$, dextrose $2 \%$ ) adding the required aminoacids: to strain HD93-15D his, leu, ura; to strain X2904$3 \mathrm{C}$ met, ura. Tryptophan (trp1) was the marker for plasmid selection.

The yeast vector carrying the GFP gene construction followed the steps on figure 1.

\section{RESULTS AND DISCUSSION}

The plasmid construction to express GFP in yeast cells was done first by transferring the protein gene from the pYEGFP3 plasmid to the Bluescript SKm plasmid in order to invert the insert position so that it could be cloned into the yeast plasmid (pYADE4) to express in the same reading frame direction of the $A D H 2$, which controls the expression of the GFP gene. After the plasmid construction, called pYGFP3 (Figure 2) this plasmid was used to transform yeast cells and verify its expression linked to the ADH2 promoter.
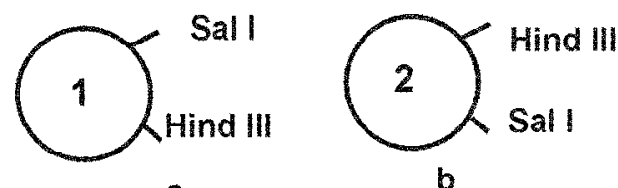

a

b
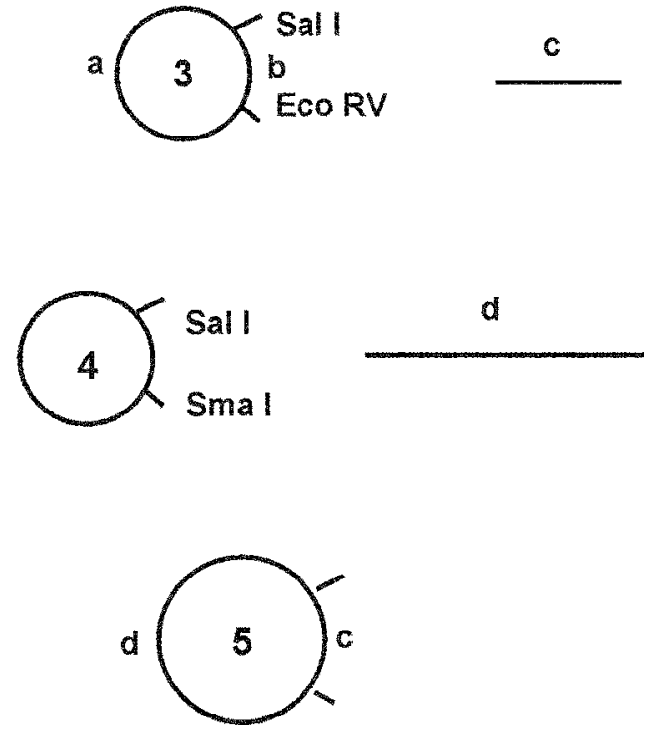

Figure 1 - The plasmid 1 (Bluescript-SKm) was cut with Sall and Hindlll endonucleases and linearized, being represented by the fragment a; the plasmid 2 (pYEGFP3) was cut with Sall and Hindlll endonucleases to cut the GFP3 gene, represented by the fragment $b$, the fragments $a$ and $b$ were bound to form plasmid 3 (Bluescript-SKm with the GFP3 gene), the plasmid 3 was then cut with Sall and EcoRV, endonucleases, originating the fragment $c$. The plasmid 4 (pYADE4) was also cut with Sall and Smal endonucleases to be linearized, represented by the fragment $d$. The binding of the fragment $c$ with the fragment $d$ built up the plasmid 5 (pYADE4with the GFP3 gene). 


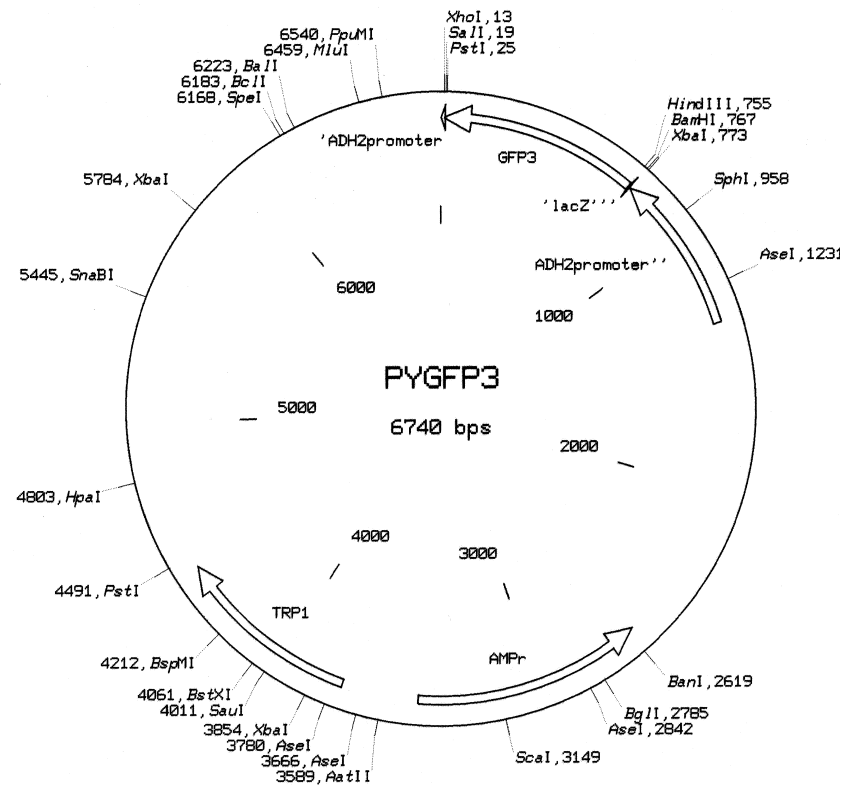

Figure 2 - Restriction Map of the Plasmid pYGFP3.

The yeast-transformed cells were stripped into a Petri dish with the minimum medium for Saccharomyces cerevisiae, together with the non-transformed yeast (Figure 3). Once the gene is linked to the ADH2 promoter, its expression occurs only under conditions of low sugar concentration and in this conditions the gene is not expressing during the fermentation process due to the fact that ADH2 is repressed by glucose. To make a spoilage monitoring of the fermentation batches a sample can be taken, stripped into a Petri dish YEPD medium (Yeast extract $0,5 \%$, peptone $0,5 \%$, dextrose $2 \%$ ) and incubated at $30{ }^{\circ} \mathrm{C}$ for 48 hours. The colonies should be observed on ultra violet light (Figure 4).

\section{CONCLUSION}

The yeast transformed cells with the pYGFP3 plasmid express the GFP gene under low sugar concentration conditions during the fermentation process, acting as an excellent marker for monitoring spoilage yeast in industrial processes.

\section{ACKNOWLEDGEMENTS}

To Dr. Alistair J.P. Brown (University of Alberdeen, UK) and Dr. Brendan P. Cormack (Johns Hopkins University, USA) for sending the pYEGFP3 plasmid and making this work possible. Our thanks also Dr. Gonçalo A.G. Pereira (Unicamp/Brazil), Dr. Walter Maccheroni Junior (USP/ESALQ), Dr. Sergio Echeverrigaray (University of Caxias do Sul) for the friendship and technical support.

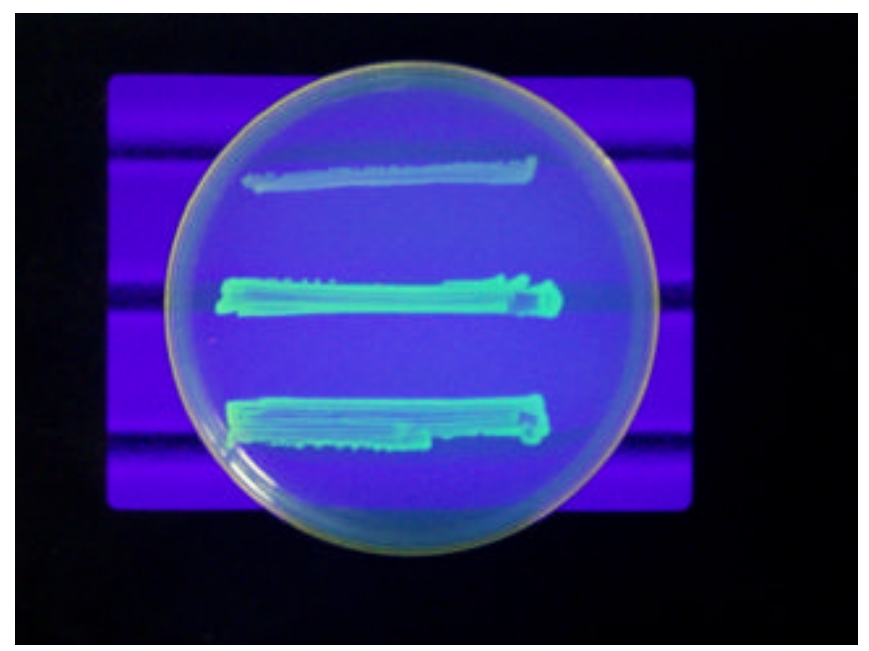

Figure 3 - Petri dish where the non-transformed yeast was grown (the upper part of the dish) and two transformed yeast strains with the GFP3 gene, HD9315D at the center and X2904-3C, below.

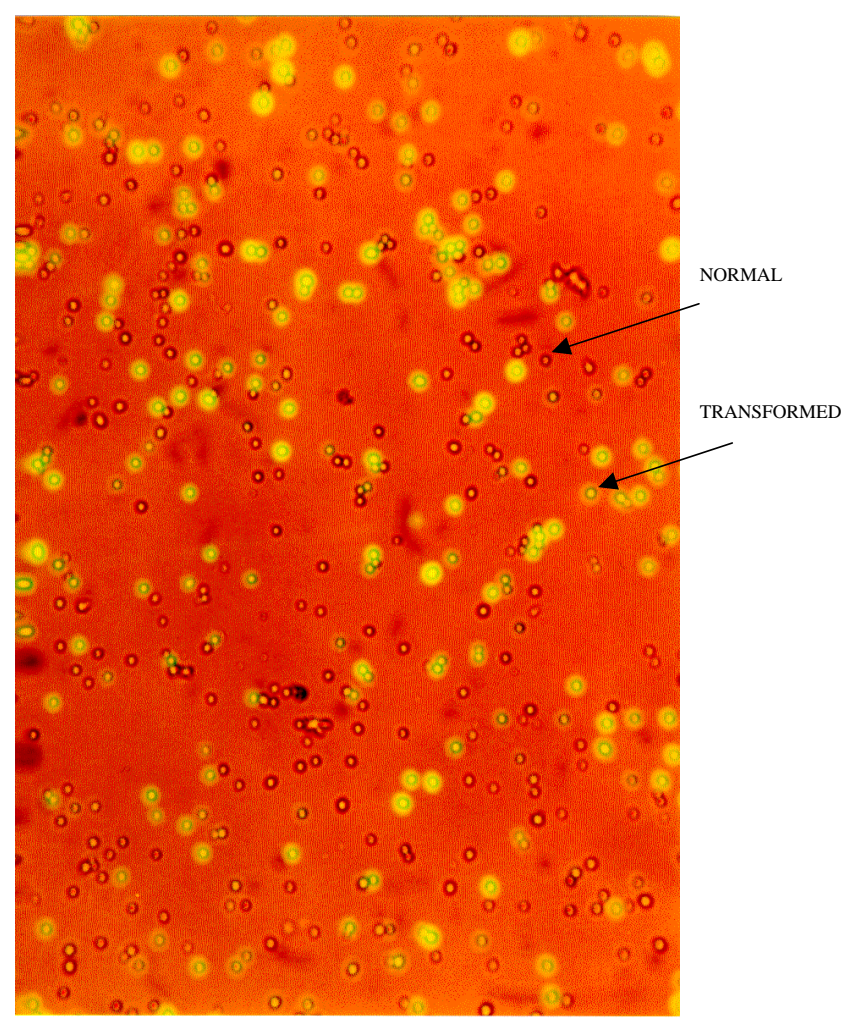

Figure 4 - Fluorescence Microscope Photograph (400X) where the fluorescent colonies from the transformed yeast cells (X2904-3C) and the opaque colonies, from the non transformed yeasts cells can be observed.

\section{REFERENCES}

AMSTERDAM, A.; LIN, S.; MOSS, L.; HOPKINS, N. Requirements for green fluorescent protein detection in trangenic zebrafish embryos. Gene, v.173, p.99-103, 1996. 
BENDOVÁ, O.; RICHTER, V.; JANDEROVÁ, B.; HAÜSLER, J. Identification of industrial yeast strains of Saccharomyces cerevisiae by fatty acid profiles. Applied Microbiology and Biotechnology, v.35, p.810-812, 1991.

BRUNELLI, J.P.; PALL, M.L. A series of yeast/ Escherichia coli I expression vectors designed for directional cloning of cDNAs and cre/lox-mediated plasmid excision. Yeast, v.9, p.1309-1318, 1993.

CASPER, S.; HOLT, C. Expression of the green fluorescent protein-encoding gene from tobaco mosaic virus-based vector. Gene, v.173, p.69-73, 1996.

CHALFIE, M.; TU, Y.; EUSKIRCHEN, G.; WARD, W.W.; PRASHER, D. Green fluorescent protein as a marker for gene expression. Science, v.293, p.802-805, 1994.

CORMACK, B.P.; BERTRAM, G.; EGETON, M.; GOW, N.A.R.; FALKOW, S.; BROWN, A.J.P. Yeast-enhanced green fluorescent protein (yEGFP): a reporter of gene expression in Candida albicans. Microbiology, v.143, p.303-311, 1997.

DOHMEN, R. J.; STRASSER, A.W.M.; HONER, C.B.; HOLLENBERG, C.P. An efficient transformatio procedure enabling long-term storage of competent cells of various yeast genera. Yeast, v.7, p.691-692, 1991.

EPEL, B.; PADGETT, H.; HEINLEIN, M.; BEACHY, R. Plant virus movement protein dynamics probed with a GFP-protein fusion. Gene, v.173, p.75-79, 1996

GOMES, L.H. Avaliação de quatro métodos para caracterização de leveduras. Piracicaba, 1995. 89p. Dissertação (Mestrado) - Escola Superior de Agricultura "Luiz de Queiroz", Universidade de São Paulo.

GORIN, P.A.J.; SPENCER, J.F.T. Proton magnetic resonance spectroscopy, an aid in idenfication and chemotaxonomy of yeasts. Advances in Applied Microbiology, v.13, p.25-89, 1970.

GUTIERREZ, L.E. Acúmulo de trealose em leveduras de Saccharomyces durante a fermentação alcoólica. Anais da ESALQ, v.47, p.597-608, 1990.

KAHANA, J.; SCHAPP, B.; SILVER, P. Kinetics of spindle pole body separation in budding yeast. Proceedings of the National Academy of Science of the USA, v.92, p.9707-9711, 1995.

KILIAN, S.G.; DEEMTER, A.; KOCK, J.L.F.; PREEZ, J.C. Ocurrence and taxonomic aspecto of proton movements coupled to sugar transport in the yeast genus Kluyveromyces. Antonie van Leeuwenhock, v.59, p.199-206, 1991.
KNIGHT, A.W.; GODDARD, N.J.; FIELDEN, P.R.; BARKER, M.G.; BILLINTON, N.; WALMSLEY, R.M. Development of a flowthrough detector for monitoring genotoxic compounds by quantifying the expression of green fluorescent protein in genetically modified yeast cells. Measure Science Technology, v.10, p.211-217, 1999.

KURTZMAN, C.P.; PHAFF, H.J. Molecular taxonomy. In: ROSE, A.H.; HARRISON, J.S. (Ed.) The yeasts. London: Academic Press, 1987. v.1, p.63-94.

MANDEL, M.; HIGA, A. Calcium dependent bacteriophage DNA infection. Journal of Molecular Biology, v.53, p.154-158, 1970.

MILLER, J.H. Experiments in molecular genetics. New York: Cold Spring Harbor Laboratory, 1972. 283p.

MILLER, R.; GALSTON, G. Rapid methods for the detection of yeast and Lactobacilus by ATP bioluminescence. Journal of the Institute of Brewing, v.95, p.317-319, 1989.

SIMPSON, W.J.; FERNANDEZ, J.L.; HAMMOND, J.R.M. Differentiation of brewery yeasts using a disc-difusion test. Journal of the Institute of Brewing, v.98, p.33-36, 1992.

TAVARES, F.C.A Control of spoilage yeasts in fuel ethanol production. Biotechnology Letters, v.17, p.1121-1126, 1995.

TAVARES, F.C.A; ECHEVERRIGARAY, S.; GOMES, L.H.; SOUBIHE, M. Identificação molecular de leveduras da fermentação alcoólica. STAB-Açúcar, Álcool e Subprodutos, v.10, p.34-39, 1992.

TSUCHIYA, T.; FUKAZAWA, Y.; KAWARITA, S. Significance of serological studies on yeasts. Mycologia Applicata, v.26, p.1-5, 1965.

WANG, S. ; HAZELRIGG, T. Implications for bcd mRNA localization from spatial distribution of exu protein in Drosophila oogenesis. Nature, v.369, p.400-403, 1994.

YAMADA, Y.; NOJIRI, M.; MATSUYAMA, M.; KONDO. K. Coenzyme $Q$ system in the classification of the ascoporogenous yeast Genera Debaryomyces, Saccharomyces, Kluyveromyces and Endomycopsis. Journal of General and Applied Microbiology, v.23, p.325-339, 1976.

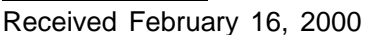

